Journal of Applied Pharmaceutical Science Vol. 6 (06), pp. 119-122, June, 2016

Available online at http://www.japsonline.com

DOI: $10.7324 / \mathrm{JAPS} .2016 .60621$

ISSN 2231-3354 (cc)) EY-NC-SA

\title{
In vitro antioxidant and cytotoxic activity of Zanthonitrile isolated from Zanthoxylum alatum
}

\author{
Indrajit Karmakar, Sagnik Haldar, Mainak Chakraborty, Saikat Dewanjee, Pallab Kanti Haldar* \\ Department of Pharmaceutical Technology, Jadavpur University, Kolkata-700032, India.
}

\begin{tabular}{|c|c|}
\hline ARTICLE INFO & ABSTRACT \\
\hline Article history: & \multirow{7}{*}{$\begin{array}{l}\text { The present study evaluates the antioxidant and cytotoxic activity of Zanthonitrile isolated from Zanthoxylum } \\
\text { alatum leaves. The structure of Zanthonitrile [\{4-[(3-Methyl-2-buten-1-yl) oxy] phenyl }\} \text { acetonitrile }] \text { was } \\
\text { elucidated form the data obtained from UV, IR, Mass, and NMR. The in vitro antioxidant activity of } \\
\text { Zanthonitrile was estimated by standard 1, 1-diphenyl-2-picrylhydrazil radical (DPPH) scavenging assay } \\
\text { method. In vitro cytotoxicity was determined in Ehrlich Ascites Carcinoma (EAC) cells by MTT assay. The } \\
\text { compound exhibited antioxidant activity in a dose dependent manner. The IC } \text { f }_{50} \text { value of Zanthonitrile for DPPH } \\
\text { was estimated to be } 7.86 \pm 0.23 \mu \mathrm{g} / \mathrm{mL} \text {. Zanthonitrile showed satisfactory cytotoxic potential in MTT assay with } \\
\text { the IC } \mathrm{I}_{50} \text { value } 57.28 \pm 0.64 \mu \mathrm{g} / \mathrm{mL} \text {. Satisfactory results of both the studies correlate each other and further } \\
\text { investigations will focus on in vivo models and cell cycle to determine the role on intrinsic and extrinsic } \\
\text { apoptotic pathways. }\end{array}$} \\
\hline Received on: $20 / 01 / 2016$ & \\
\hline Revised on: 08/02/2016 & \\
\hline Accepted on: 24/03/2016 & \\
\hline Available online: $28 / 06 / 2016$ & \\
\hline Key words: & \\
\hline $\begin{array}{l}\text { Zanthonitrile; Zanthoxylum } \\
\text { alatum; cytotoxicity, } \\
\text { antioxidant. }\end{array}$ & \\
\hline
\end{tabular}

\section{INTRODUCTION}

Zanthoxylum alatum Roxb. (Family: Rutaceae) is an evergreen plant of the Himalayan regions in India commonly known as Tejphal (Hindi) and Timur (Nepal) (Tiwary et al., 2007; Singh and Singh, 2011).

Nepalese traditionally used the fruit decoction in abdominal pain, bark extract as cholera, diabetes and asthma. Pickles from the fruits are used by Nepalese for treating cold \& cough, tonsillitis, headache, fever and high altitude sickness (Geweli and Awale, 2008). Different parts of the plant are traditionally used as a stomachic, carminative, disinfectant, antiseptic. The plant is also used for the treatment of fever, dyspepsia, cholera, anthelmintic, general debility (Jain et al., 2001; Kalia et al., 1999). It has been proven that the plant have the antibacterial, antifungal, anthelmintic and larvicidal activities

* Corresponding Author

Dr. Pallab Kanti Haldar, Department of Pharmaceutical Technology,

Jadavpur University, Kolkata-700032, India.

Email:pallab_haldar@rediffmail.com
(Tiwary et al., 2007). As well as hepatoprotective (Ranawat et al., 2010), antinociceptive, anti-inflammatory (Guo et al., 2011), antipyretic activities, antioxidant and antimicrobial activities have been also proven (Karmakar et al., 2015a). Cellular and nuclear damage activities and antitumor activities were also determined recently (Karmakar et al., 2015b). Various phytopharmaceuticals like berberine, dictamnine, xanthoplanine, armatamid, asarinin and fargesin, alpha and beta-amyrins and lupeol are present in the plant (Kalia et al., 2015; Nadkarni, 2002). The aim of the present study was structure elucidation of the isolate and its antioxidant and cytotoxic activity.

\section{MATERIALS AND METHODS}

\section{Plant materials}

Zanthoxylum alatum leaves were collected from the hilly region of Gangtok, Sikkim, India. The plant material was identified by the Botanical Survey of India, Howrah, West Bengal, India. A voucher specimen $(\mathrm{CNH} / 38 / 2014 / \mathrm{Tech}$. II/78) has been preserved in our laboratory for future reference. 


\section{Extraction and Isolation}

Dried powdered leaves $(1.1 \mathrm{~kg})$ were consecutively extracted by petroleum ether $(7.4 \% \mathrm{w} / \mathrm{w}$, yield), chloroform $(9.1 \%$ $\mathrm{w} / \mathrm{w}$, yield) and methanol (10.6\% w/w, yield) by using soxhlet apparatus. The solvents were completely removed under reduced pressure in a rotary vacuum evaporator (Buchi R-210). The concentrated extracts were stored in vacuum desiccators for further use. The isolation process was done for chloroform extract on column chromatography over silica gel (60-120 mesh). Hexane, ethyl acetate and methanol were eluted according to increase the polarity. An amorphous powder was found by eluted the solvent hexane: ethyleacetate (85:15) and characterized by ultra violetvisible (UV-vis), infrared spectroscopy (IR), mass spectrometry and proton and carbon-13 nuclear magnetic resonance (NMR).

\section{In vitro antioxidant activity}

Antioxidant property of Zanthonitrile (1, 5, 10, 25, 50 $\mu \mathrm{g} / \mathrm{ml}$ ) was determined in triplicate by DPPH radical scavenging activity according to the standard method (Karmakar et al., 2011). The $50 \%$ inhibitory concentration $\left(\mathrm{IC}_{50}\right)$ was calculated from graph as concentration versus percentage inhibition using the previously used formula.

\section{In vitro cytotoxic activity}

Ehrlich ascites carcinoma (EAC) cells were obtained from Chittaranjan National Cancer Institute, Kolkata, India prior to the experiment and maintained in Swiss albino mice according to the standard protocol (Karmakar et al., 2013). In vitro cytotoxicity of Zanthonitrile was determined using standard MTT assay with some modification (Nikhil et al., 2014). In brief, EAC cells $\left(3 \times 10^{5}\right.$ $\mathrm{ml}^{-1}$ ) were seeded into 96-well flat microtiter plates in enriched RPMI 1640 medium $(200 \mu \mathrm{l})$ supplemented with penicillin (100 $\mathrm{IU} / \mathrm{ml})$ and streptomycin $(100 \mu \mathrm{g} / \mathrm{ml})$. Different concentrations Zanthonitrile $(10,25,50,100 \mu \mathrm{g} / \mathrm{ml})$ was added to the cell in the volume of $100 \mu \mathrm{l} /$ well. All samples were incubated for $24 \mathrm{~h}$ at 37 ${ }^{\circ} \mathrm{C}$ in a humidified incubator with $5 \%$ of $\mathrm{CO}_{2}$. After $24 \mathrm{~h}$, the medium was removed and cell cultures were incubated with $20 \mu \mathrm{l}$ MTT reagent $(5 \mathrm{mg} / \mathrm{ml})$ for $4 \mathrm{~h}$ at $37{ }^{\circ} \mathrm{C}$. DMSO $(150 \mu \mathrm{l})$ was added for to remove the formazan produced by the viable cells. The suspension was placed on micro-vibrator for $5 \mathrm{~min}$ and absorbance was recorded at $570 \mathrm{~nm}$ by the ELISA reader. The experiment was performed in triplicate. The percentage cytotoxicity was calculated using the following formula.

The percentage inhibition was calculated as=

$$
100-[(\text { Mean OD of treated cell } \times 100)
$$

mean OD of vehicle treated cells (negative control)] The $\mathrm{IC}_{50}$ values were calculated using graph pad prism, version 5.02 software (Graph Pad Software Inc.,CA, USA).

\section{Statistical analysis}

Statistical analysis was performed using Graph Pad Prism (version 5.02, San Diego, California) Software. All data are expressed as mean \pm standard error of mean (SEM).

\section{RESULTS AND DISCUSSION}

The present study showed that treatment with the Zanthonitrile obtained from Zanthoxylum alatum leaves possesses antioxidant and cytotoxic activity. Since bioactive compounds occurring in plant material consist of multi-component mixtures, their separation and determination still creates problems.

Zanthonitrile (4-[\{3'-methyl-2'-buten-1'-yl $\}$ oxy] phenyl acetonitrile) was isolated from Zanthoxylum alatum as a light yellow colored liquid. The ESI-MS spectral data showed molecular ion $[\mathrm{M}]^{+}$at $\mathrm{m} / \mathrm{z}, 201$, indicating a molecular formula of $\mathrm{C}_{13} \mathrm{H}_{15} \mathrm{NO}$. The IR spectrum revealed nitrile absorption at $2257.13 \mathrm{~cm}^{-1}$. The $1 \mathrm{H}$ NMR spectrum of isolated compound showed two singlates at $6.53 \mathrm{ppm}[(2 \mathrm{H}, \mathrm{d}, J) 8.6 \mathrm{~Hz}, \mathrm{H}-3$ and $\mathrm{H}-5)]$ and $6.91[(2 \mathrm{H}, \mathrm{d}, J) 8.6 \mathrm{~Hz}, \mathrm{H}-2$ and $\mathrm{H}-6)]$ describing presence of a 1,4-disubstituted benzene. Furthermore, one substituent was proved to be a 3,3-dimethylallyloxyl group at $5.51 \mathrm{ppm}[(2 \mathrm{H}, \mathrm{d}, J)$ $\left.6.8 \mathrm{~Hz}, \mathrm{H}-2^{\prime}\right], 5.50 \mathrm{ppm}\left[(1 \mathrm{H}, \mathrm{t}, J) 6.8 \mathrm{~Hz}, \mathrm{H}-2^{\prime}\right], 1.72$ and 1.76 ppm (each $3 \mathrm{H}, \mathrm{s}, \mathrm{H}-4^{\prime}$ and $\left.\mathrm{H}-5^{\prime}\right)$ ), and acetonitrile $\mathrm{CH}_{2}$ - substituent proton was observed as a singlet at $3.68 \mathrm{ppm}(2 \mathrm{H}, \mathrm{H}-1 ")$. $13 \mathrm{C}$ NMR spectra confirmed the acetonitrile substituent through the peak at 23.1ppm (C-1") and a nitrile peak at 118.7 (C-2"). ESI-MS spectral data showed the presence of a prominent fragments at $\mathrm{m} / \mathrm{z}$ $69\left[\mathrm{CH}_{2} \mathrm{CHC}\left(\mathrm{CH}_{3}\right)_{2}\right]+$ and $\mathrm{m} / \mathrm{z} 133\left[\mathrm{HOC}_{6} \mathrm{H}_{4} \mathrm{CH}_{2} \mathrm{CN}\right]+$ indicates the presence of 2-methyl butene and 4-hydroxy phenyl acetonitrile indicates presence of 4-[\{3'-methyl-2'-buten-1'-yl $\}$ oxy] phenyl acetonitrile which is named as zanthonitrile.

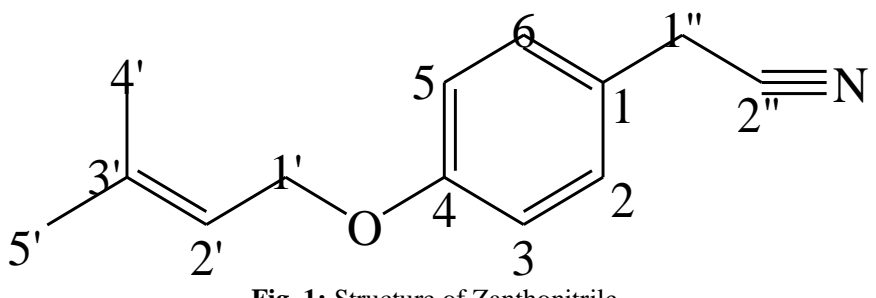

Fig. 1: Structure of Zanthonitrile.

Free radical is a molecule which has a single unpaired electron in an outer orbital. It may produce many diseases like cancer, arthritis and neurological disorder by the oxidative damage to the cells. The antioxidant effect on DPPH is believed to be due to their hydrogen-donating ability (Ashafa et al., 2010). DPPH assay is the most widely reported in vitro method using for screening of antioxidant activity based on the reduction of colored free radical DPPH by free radical scavenger. DPPH gives violet color stable, nitrogen-centred free radical in methanol solution which was reduced to yellow colored diphenylpicryl hydrazine, with the addition of Zanthonitrile in a concentration-dependent manner (Karmakar et al., 2011). The assay showed the inhibitory ability of Zanthonitrile and standard ascorbic acid on DPPH in a concentration dependent manner with the $\mathrm{IC}_{50}$ values $7.86 \pm 0.23$ $\mu \mathrm{g} / \mathrm{ml}$, and $9.17 \pm 0.39 \mu \mathrm{g} / \mathrm{ml}$ (Fig. 2) which indicates the efficient DPPH scavenging activity.

In vitro cytotoxicity of Zanthonitrile was evaluated by the MTT reduction assay, after $24 \mathrm{~h}$ of exposure in culture. The 
assay showed cytotoxic effect of Zanthonitrile on the EAC cell in a concentration dependent manner. The $\mathrm{IC}_{50}$ value was found to be $57.28 \pm 0.64 \mu \mathrm{g} / \mathrm{ml}$ by plotting the graph concentration versus percentage inhibition (Fig. 3).

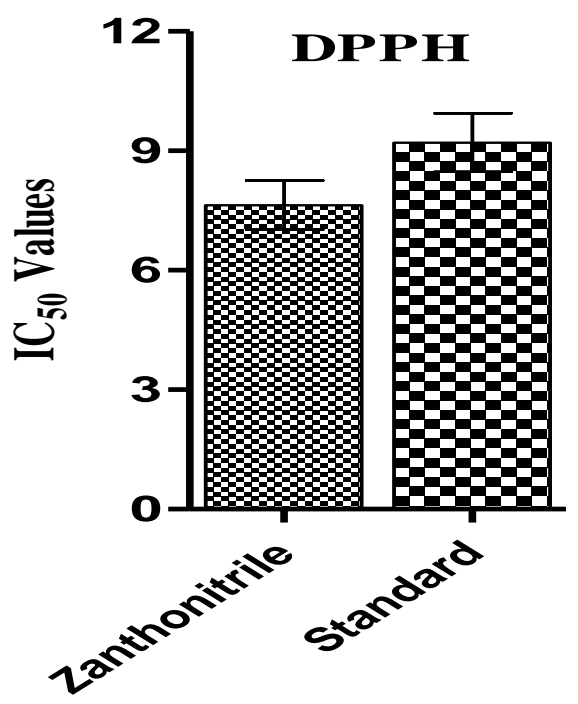

Fig. 2: The $\mathrm{IC}_{50}$ values of Zanthonitrile and standard for DPPH are $7.64 \pm 0.62$ $\mu \mathrm{g} / \mathrm{ml}$ and $9.21 \pm 0.74 \mu \mathrm{g} / \mathrm{ml}$; The results are mean \pm SEM of three experiments.

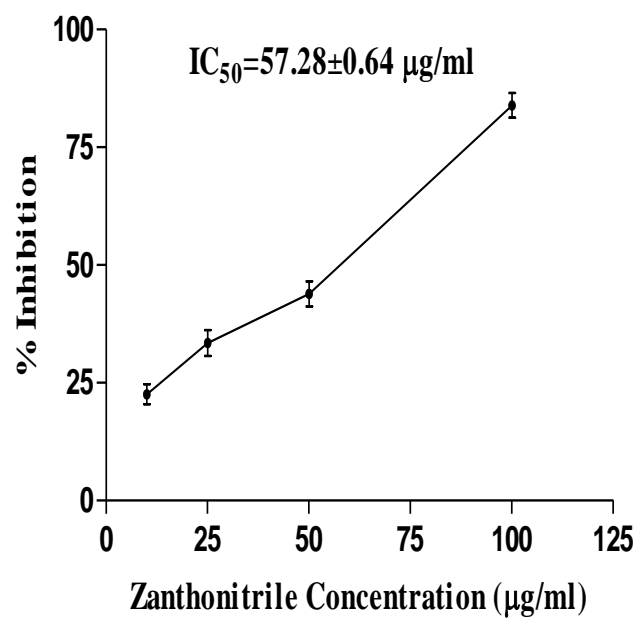

Fig. 3: Cytotoxic effect of Zanthonitrile on in vitro EAC cell. Values are mean \pm S.E.M.; where $\mathrm{n}=3$.

The Ehrlich ascites carcinoma (EAC) cells are available as gray-white or light bloody viscose liquid. It referred to as rapid proliferation, undifferentiated carcinoma, shorter life span and $100 \%$ malignancy. EAC has a resemblance with human tumors which are the most sensitive to chemotherapy due to the fact that it is undifferentiated and that it has a rapid growth rate (Ozaslan et al., 2011). The cytotoxic effect of Zanthonitrile was investigated in vitro using MTT assay. MTT assay measured the cell viability based on the reduction of yellow tetrazolium MTT to a purple formazan dye mitochondrial dehydrogenase enzyme. So, the amount of formazan produced reflected the number of metabolically active viable cells (Zare Shahneh et al., 2013). MTT results showed that Zanthonitrile possessed cytotoxic effect against EAC cell lines in a dose-dependent manner.

\section{CONCLUSION}

The isolate Zanthonitrile, proves to a potent antioxidant as is evidenced from the DPPH radical scavenging activity. It also has antitumor properties as is evinced from the in vitro cytotoxicity test and hence warrants further investigation of this compound in cancer research.

\section{CONFLICT OF INTEREST}

We declare that we have no conflict of interest.

\section{ACKNOWLEDGEMENTS}

We greatly acknowledge the Department of Science and Technology (DST), Govt. of India, for the INSPIRE fellowship [IP120448] sanction no. DST/INSPIRE Fellowship/2012/423 to the first author (IK); the Jadavpur University and Chittaranjan National Cancer Institute, Kolkata, India for the technical support.

\section{REFERENCES}

Ashafa AOT, Grierson DS, Afolayan AJ. In vitro antioxidant activity of extracts from the leaves of Felicia muricata Thunb. An underutilized medicinal plant in the eastern cape province, South Africa. Afr J Tradit Complement Altern Med, 2010; 7:296-302.

Geweli MB, Awale S. Aspects of Traditional Medicine in Nepal, Institute of Natural Medicine University of Toyama, Japan; 2008, pp. 140-142.

Guo T, Deng YX, Xie H, Yao CY, Cai CC, Pan SL, et al. Antinociceptive and anti-inflammatory activities of ethyl acetate fraction from Zanthoxylum armatum in mice. Fitoterapia, 2011; 82:347-351.

Jain N, Srivastava SK, Aggarwal KK, Ramesh S, Kumar S. Essential oil composition of Zanthoxylum alatum seeds from northern India. Flavour Frag, J 2001; 16:408-410.

Kalia N, Singh B, Sood R. A new amide from Zanthoxylum armatum. J Nat Prod, 1999; 62:311-312.

Karmakar I, Dolai N, Kumar RBS, Kar B, Roy SN., Haldar PK. Antitumor activity and antioxidant property of Curcuma caesia against Ehrlich's Ascites Carcinoma bearing mice. Pharm Biol, 2013; 51:753-759.

Karmakar I, Dolai N, Saha P, Sarkar N, Bala A, Halder PK. Scavenging activity of Curcuma caesia rhizome against reactive oxygen and nitrogen species. Orient Pharm Exp Med, 2011; 11: 221-228.

Karmakar I, Haldar S, Chakraborty M, Chaudhury K, Dewanjee S, Haldar P K. Regulation of apoptosis through bcl-2/bax proteins expression and DNA damage by Zanthoxylum alatum. Pharm Biol, 2015b; 54: 503-508.

Karmakar I, Haldar S, Chakraborty M, Dewanjee S, Haldar P K. Antioxidant and Cytotoxic Activity of Different Extracts of Zanthoxylum Alatum. Free Rad Antiox, 2015a; 5:21-28.

Nadkarni AK. Nadkarni's Indian Material Medica, vol. I Rep. ed. Popular Prakashan, Mumbai; 2002, pp. 569-570.

Nikhil K, Sharan S, Chakraborty A, Bodipati N, Krishna Peddinti R, Roy P. Role of isothiocyanate conjugate of pterostilbene on the inhibition of MCF-7 cell proliferation and tumor growth in Ehrlich ascitic cell induced tumor bearing mice. Exp Cell Res, 2014; 320 (2):311328. 
Ozaslan M, Karagoz ID, Kilic IH, Guldur ME. Ehrlich ascites carcinoma. Afr J Biotechnol, 2011; 10(13):2375-2378.

Ranawat L, Bhatt J, Patel J. Hepatoprotective activity of ethanolic extracts of bark of Zanthoxylum armatum $\mathrm{DC}$ in $\mathrm{CCl}_{4}$ induced hepatic damage in rats. J Ethnopharmacol, 2010; 127:777-780.

Singh TP, Singh OM. Phytochemical and pharmacological profile of Zanthoxylum armatum DC. An overview. Indian J Nat Prod Resour, 2011; 2:275-285.

Tiwary M, Naik SN, Tewary DK, Mittal PK, Yadav S. Chemical composition and larvicidal activities of the essential oil of Zanthoxylum armatum DC (Rutaceae) against three mosquito vectors. J Vector Borne Dis, 2007; 44:198-204.
Zare Shahneh F, Baradaran B, Orangi M, Zamani F. In vitro Cytotoxic Activity of Four Plants Used in Persian Traditional Medicine. Adv Pharm Bull, 2013; 3(2):453-455.

\section{How to cite this article:}

Indrajit Karmakar, Sagnik Haldar, Mainak Chakraborty, Saikat Dewanjee, Pallab Kanti Haldar. In vitro antioxidant and cytotoxic activity of Zanthonitrile isolated from Zanthoxylum alatum. J App Pharm Sci, 2016; 6 (06): 119-122. 